\title{
Physical and physicochemical characteristics, bioactive compounds and antioxidant activity of xiquexique (Pilosocereus gounellei (A. Weber ex K. Schum.)) fruit
}

\author{
Características físicas e físico-químicas, compostos bioativos \\ e atividade antioxidante do fruto de xiquexique (Pilosocereus \\ gounellei (A. Weber ex K. Schum.))
}

\author{
Antonia Almeida da Silva ${ }^{1}$; Renato Lima Dantas ${ }^{2}$; Claudiana dos Santos Véras ${ }^{1}$; \\ Ricardo Elesbão Alves ${ }^{3}$; Silvanda de Melo Silva ${ }^{4 *}$
}

\begin{abstract}
Many native species from the Cactaceae family with occurrence in northeastern Brazil have been investigated targeting their chemical composition and functional properties as strategy of adding value to these species that are underexploited according to ethnobotanical studies. The xiquexique (Pilosocereus gounellei (A. Weber ex K. Schum.)) is one of these species that adapts in high temperatures and low rainfall environments and some local populations use it for several purposes, including animal feeding and medicinal. However, there is few studies regarding the physical and physicochemical characterization and on the compounds of functional interest in fruits of this species. In the context, the aim of this study was to evaluate the physical and physicochemical characteristics, bioactive compounds and antioxidant activity of the xiquexique fruit from plants occurring in three municipalities of the state of Paraíba, Brazil. The pulp of fruits from the municipalities of Boqueirão and Solânea presented lower acidity content, with higher SS/AT ratio and may be more suitable for fresh consumption. Furthermore, fruits from these municipalities can be also attractive for processing once they had larger sizes. Fruits of xiquexique exhibited high contents of functional compounds such as phenolic and betalains, which provided high antioxidant activity, with potential for adding value.
\end{abstract}

Key words: Betalains. Betacyanins. Cactaceae. Functional potential. Native fruits. Polyphenols.

\section{Resumo}

Diversas espécies nativas da família Cactaceae de ocorrência no Nordeste do Brasil têm sido estudadas quanto à qualidade, composição química e propriedades funcionais como estratégia de agregação de valor às essas espécies que são subutilizadas de acordo com estudos etnobotânicos. O xiquexique (Pilosocereus gounellei (A. Weber ex K. Schum.)) é uma dessas espécies que se adapta em ambientes com temperaturas elevadas e baixa pluviosidade e é utilizada pela população local para diversos usos, inclusive na alimentação animal e medicinal. Contudo, há escassez de estudos voltados para a determinação de compostos funcionais nos frutos desta espécie. Neste contexto, o objetivo deste

1 Discentes de Mestrado, Programa de Pós-Graduação em Agronomia, Universidade Federal da Paraíba, UFPB, Areia, PB, Brasil. E-mail: antoniaalmeidaufpb@gmail.com; claudiana_stsveras@hotmail.com

2 Prof. Dr., Faculdade de Enfermagem Nova Esperança, FACENE, João Pessoa, PB, Brasil. E-mail: renatodantas@facene.com.br

3 Pesquisador, Dr., Empresa Brasileira de Pesquisa Agropecuária, EMBRAPA Agroindústria Tropical, Fortaleza, CE, Brasil. E-mail: elesbão@cnpat.embrapa.br

${ }^{4}$ Prof $^{a}$ Dr $^{\text {a }}$, Universidade Federal da Paraíba, UFPB, Areia, PB, Brasil. E-mail: silvasil@cca.ufpb.br

* Author for correspondence 
trabalho foi avaliar as características físicas e físico-químicas, os compostos bioativos e a atividade antioxidante de frutos de xiquexique provenientes de três municípios do estado da Paraíba. A polpa dos frutos dos municípios de Boqueirão e Solânea apresentou conteúdo de acidez mais baixo, com relação SS/AT elevada, podendo se adequar para consumo fresco. Além disso, os frutos destes municípios por apresentarem maior tamanho podem também ser atrativos para o processamento. Os frutos de xiquexique apresentam altos conteúdos de compostos funcionais, a exemplo de compostos fenólicos e de betalaínas, o que proporcionou elevada atividade antioxidante, com potencial de agregação de valor.

Palavras-chave: Betalaínas. Betacianinas. Cactaceae. Frutas nativas. Polifenóis. Potencial funcional.

\section{Introduction}

The Cactaceae family belongs to the angiosperm plant group and are the second most numerous group of plants in the Neotropical region. It grows in a wide diversity of climates, soils and ecosystems (SBRISSA; MELLO, 2012). The occurrence of these species in Brazil is mainly concentrated in the Southeast and Northeast regions, where they are used in the most diverse uses, including human alimentation (LUCENA et al., 2013).

Although the forage potential of cacti is relevant, other forms of use among species have been reported, such as the fresh consumption of mandacaru (C. jamacaru) fruit (LUCENA et al., 2013; MELO et al., 2017). Studies have shown that cacti fruits have quality characteristics suitable for both fresh consumption and processing, aiming to improve the use of these fruits. The physicochemical characterization of these non-traditional fruits aims to identify appropriate attributes for consumption and to define the harvest point (DANTAS et al., 2015b). Therefore, studies on this purpose in xiquexique fruit are important, especially those that approach the functional quality.

Xiquexique (Pilosocereus gounellei (A. Weber ex K. Schum.)) is a columnar cactus that stands out in relation to some other species of cacti family, because it presents greater resistance in areas with low rainfall and grows on rocks, allowing it to be used in ruminant feeding during prolonged periods of drought. Its ripe fruit has a thick peel, which tends to present cracking when it reaches advanced maturation, exposing the pulp and seeds to the environment which are then consumed by insects and birds (ARAÚJO et al., 2010). Additionally, rural communities in the state of Paraíba use the stem pulp to make cookies, cakes and jams (LUCENA et al., 2013).

According to Silva et al. (2009), the cacti present fruit, which is considered a functional food due to its high content of bioactive compounds, allowing it to be used as a healthy food alternative. However, there are few studies exploring the nutritional and functional quality of xiquexique fruit. Thus, it has to be considered that it presents the potential to be consumed in the human diet as a possible source of compounds of functional interest.

Phenolic compounds are distributed among the different plants organs and have been highlighted for being more significantly found in fruits, vegetables and their derivatives, being natural phytochemicals of food origin with remarkable antioxidant properties (LI-CHAN, 2015; MELO et al., 2017). In this sense, studies have highlighted several biological effects of polyphenols due to their ability to reduce reactive oxygen species (ROS), modulating the activity of some specific enzymes and thus inhibiting cell proliferation (SPENCER et al., 2008).

Betalains are strong natural antioxidants similar to phenolic compounds (MOUSSA-AYOUB et al., 2011). In addition, these pigments are of great importance for food industries that use natural colorant in their products, which adds value and enhances consumer acceptance. Furthermore, betalains are the most characteristic phytochemicals of Cactaceae, and in general the concentration increases as the fruits ripen (CASTELLAR et al., 2012; DANTAS et al., 2015a). 
Nevertheless, there is little information addressing either the functional potential of xiquexique fruit or its quality aspects. Therefore, the objective of this work was to evaluate the physical and physicochemical characteristics, bioactive compounds and antioxidant activity of xiquexique fruit from three municipalities in the state of Paraíba.

\section{Material and Methods}

Fruits of xiquexique (P. gounellei (A. Weber ex K. Schum.)) were harvested when ripe, then presenting a purplish coloration for its peel, and no visible evidence of cracking. All fruits were harvested from naturally occurring plants in the rural areas of the municipalities of Boqueirão, Solânea and São Mamede, located in regions of different bioclimates in the state of Paraíba: Cariri, Curimataú and Sertão, respectively. Boqueirão presents a semiarid climate (hot and dry), according to Köppen-Geiger climate classification, with maximum temperature around $37^{\circ} \mathrm{C}$ and minimum of $16^{\circ} \mathrm{C}$. In Solânea, the climate is rainy tropical type, with dry summer and a mean annual temperature around $25{ }^{\circ} \mathrm{C}$. São Mamede is characterized by dryness and risk of drought due to the low rainfall indexes and the climate, according to Köppen classification, is Bsh (hot semiarid), with summer rains, mean annual temperature of $28^{\circ} \mathrm{C}$.

Before the analysis, fruits were washed and sanitized with $100 \mathrm{ppm}$ sodium hypochlorite solution, being afterward grouped in four replications (10 fruits each) per municipality to compose the experimental design. The peel (epicarp + mesocarp) and pulp (endocarp) were separated, being the peel macerated with a domestic grinder. The seeded pulp was macerated with the mortar and pistil.

The physical characterization comprised the measurement of length and diameter $(\mathrm{mm})$ with caliper rule; mass of the whole fruit ( $\mathrm{g}$ ) accessed by a semi-analytical scale, and firmness of the whole fruit $(\mathrm{N})$ was measured with a manual penetrometer Magness-Taylor pressure tester (DANTAS et al., 2015b). The physicochemical evaluations was according to Dantas et al. (2015b) for both, the fruit peel and pulp. The $\mathrm{pH}$ was measured using a digital $\mathrm{pHmeter}$; titratable acidity (TA, g citric acid $100 \mathrm{~g}^{-1}$ ) was determined by titration, using $0.1 \mathrm{M}$ $\mathrm{NaOH}$ solution and phenolphthalein as indicator; soluble solids content (SS, \%) was measured using the ABBE type benchtop refractometer with temperature control $\left(20{ }^{\circ} \mathrm{C}\right)$; SS/AT ratio was obtained by dividing the contents of SS and TA. Quantification of ascorbic acid (mg $100 \mathrm{~g}^{-1}$ ) was performed with modifications. One gram of the pulp sample was soaked in $5 \mathrm{~mL}$ of methanol: $\mathrm{HCl}$ solution (85:15) and manually macerated for $1 \mathrm{~min}$, until the reduction of the intense red-purple coloration. After decantation, the supernatant was removed, 50 $\mathrm{mL}$ of oxalic acid was added, and the titration with DFI (0.002\% Indophenol 2, 6-dichlorophenol) was performed. For the peel, the oxalic acid was added directly in $1 \mathrm{~g}$ of the sample, being homogenized for a later titration with DFI.

The total extractable polyphenols (TEP) and antioxidant activity were determined according to Dantas et al. (2015a) with modifications. The extract consisted of $3 \mathrm{~g}$ of the sample and $4 \mathrm{~mL}$ of $50 \%$ methanol stirred for 1 minute and standing for 1 hour. Afterward, it was applied a centrifugation at 9,000 rpm at $4{ }^{\circ} \mathrm{C}$ for 20 minutes. Thereafter, the supernatant was removed and $4 \mathrm{ml}$ of $70 \%$ acetone was added to the residue, which was stirred and centrifuged as well. The two supernatants were combined up to $10 \mathrm{~mL}$ with deionized water.

TEP content determination was performed by spectrophotometry using the Folin-Ciocalteu reagent in triplicate (DANTAS et al., 2015a). Briefly, based on prior testing, an aliquot of 100 $\mu \mathrm{L}$ of the sample was diluted (1:9) with deionized water. Additionally, $1 \mathrm{~mL}$ of Folin-Ciocalteu, $2 \mathrm{~mL}$ of $20 \%$ sodium carbonate, and $2 \mathrm{~mL}$ of deionized water were added, reaching the total volume of 6 $\mathrm{mL}$. The reading was performed at $700 \mathrm{~nm}$, after samples being kept in the dark for $30 \mathrm{~min}$ at room temperature. The TEP content was estimated using 
a standard curve of gallic acid $(r=0.999)$ and the results were expressed as mg of gallic acid per 100 $\mathrm{g}$ fresh weight.

The antioxidant activity was determined by the free radical DPPH' (1,1-diphenyl-2-picrylhydrazyl) method in triplicate, based on the standard curve of the $\mathrm{DPPH}^{\cdot}(\mathrm{r}=0.999)$. Three aliquots of the phenolic extract $\left(400,600\right.$ and $800 \mu \mathrm{L} \mathrm{mL}^{-1}$ ) were diluted in deionized water; the volume was completed to $1 \mathrm{~mL}$, giving the dilution factors of 2:3, 3:2, and 4:1 respectively. From each dilution, a $100 \mu \mathrm{L}$ aliquot and $3.9 \mathrm{~mL}$ of the $\mathrm{DPPH}^{\bullet}(0.06$ $\mathrm{mM}$ ) radical were used to obtain the final volume of $4 \mathrm{~mL}$. As a control, $100 \mu \mathrm{L}$ of the control solution $(50 \%$ methanol $+70 \%$ acetone) was used (Dantas et al., 2015a). The readings were performed at 515 $\mathrm{nm}$, after samples wait during $01 \mathrm{~h} 05 \mathrm{~min}$ (skin) and 02h30min (pulp). Preliminary tests gave this time for sample resting.

Three dilutions of the same extract were taken to calculate the antioxidant activity in $\mathrm{EC}_{50}$ ( $\mathrm{g}$ fresh sample $\mathrm{g} \mathrm{DPPH}^{-1}$ ) based on the equation of the absorbances. The amount of sample required to reduce the initial concentration of $\mathrm{DPPH}^{-1}$ radical $\left(\mathrm{EC}_{50}\right)$ by $50 \%$ was determined by replacing $50 \%$ of the absorbance of the control solution in the generated equation. This $\mathrm{EC}_{50}$ value gives a numerical parameter of how much fresh fruit is capable of capturing the free radicals in the tested model, which correlates with antioxidant substances available in the extract. All procedures were performed in the absence of light.

The contents of betalains were obtained according to Castellar et al. (2003), modified by Dantas (2015a). Ethanol:water solution (80:20, v: v) was added to $6 \mathrm{~g}$ of peel and $1 \mathrm{~g}$ of pulp using the 1:1 ratio. Thereafter, the samples were shaken for 3 minutes and centrifuged at $9000 \mathrm{rpm}, 4{ }^{\circ} \mathrm{C}$, for 15 minutes. The supernatant was removed and $7 \mathrm{~mL}$ of the extractive solution was added to the residue, repeating this above procedure. It was combined both supernatants and the final volume was set to $15 \mathrm{~mL}$ with the extractive solution. The content of betacyanins was determined by spectrophotometry at $535 \mathrm{~nm}$ and betaxanthins at $485 \mathrm{~nm}$. Estimation was according to the following equation: betacyanins/ betaxanthins $\left[\mathrm{mg} 100 \mathrm{~g} \mathrm{FW}^{-1}\right]=[(\mathrm{A} \times \mathrm{DF} \times \mathrm{MW}$ $\times \mathrm{V} \times 100 / 1 € \times \mathrm{SW})]$ where: $\mathrm{A}=$ absorbance at $535 \mathrm{~nm}$ or $485, \mathrm{DF}=$ Dilution Factor, $\mathrm{MW}=$ molecular weight of betacyanin or betaxanthin, $\mathrm{V}=$ volume of extract; $€=$ extinction coefficient; $\mathrm{SW}=$ sample weight. For the betacyanins, the extinction coefficient is $60,000 \mathrm{~L}(\mathrm{~mol} \mathrm{~cm})^{-1}$ and $\mathrm{PM}=550 \mathrm{~g}$ $\mathrm{mol}^{-1}$. For betaxanthins, the extinction coefficient is $48,000 \mathrm{~L}(\mathrm{~mol} \mathrm{~cm})^{-1}$ and $\mathrm{MW}=308 \mathrm{~g} \mathrm{~mol}^{-1}$.

The experimental design was the completely randomized, separately for the skin and pulp, in a factorial scheme, composed by fruits harvested from 3 municipalities, in 4 replications, 10 fruits each (40 fruits/municipality), 120 fruits in the total. The data were submitted to analysis of variance by the $\mathrm{F}$ test and the means compared by the Tukey test, considering up to $5 \%$ of error probability for both portions. Pearson's correlation of the bioactive compounds and antioxidant activity was performed. The evaluations were carried out through the $\mathrm{SAS}^{\circledR}$ 9.2 program.

\section{Results and Discussion}

Xiquexique fruit ( $P$. gounellei (A. Weber ex K. Schum.)) are berries with a thick mesocarp of purplish color when mature. At advanced maturity, the fruit presents a cracking mesocarp that exposes the seeded pulp to the environment, which is then consumed by insects and birds as a probable ecological dispersion strategy of the species (ARAÚJO et al., 2010). However, the fruit's endocarp consists of an intense pink-purplish mucilaginous pulp containing numerous black seeds (Figure 1). 
Figure 1. Xiquexique (Pilosocereus gounellei (A. Weber ex K. Schum.)) fruit attached to the plant, cracked and eaten by birds (A); harvested showing cracking features (B); intact ripe fruit (C); and fruit cut in halves showing the pinkpurplish pulp with seeds (D).

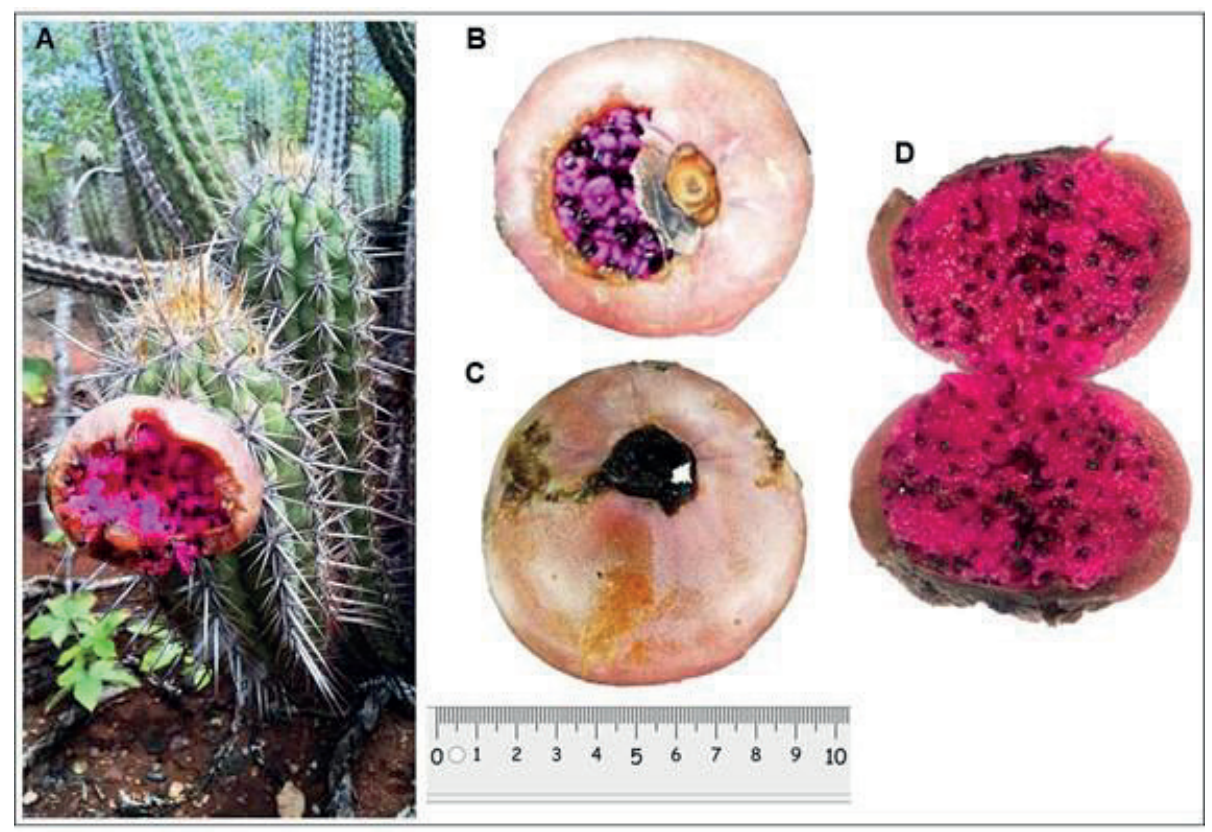

Xiquexique fruit harvested in the municipality of Solânea presented longer length, differing from the fruit grown in the municipality of São Mamede, which presented a smaller size (Table 1), and this can be related to the climatic differences between these municipalities. São Mamede is located in a warmer and drier region, and this aspect may have interfered in the fruit's development.

Table 1. Physical characteristics of ripe xiquexique (Pilosocereus gounellei (A. Weber ex K. Schum.)) fruits (purplish color), harvested from areas of occurrence of plant in three municipalities of the state of Paraíba, Brazil.

\begin{tabular}{ccccc}
\hline Municipality & Length $(\mathrm{mm})$ & Diameter $(\mathrm{mm})$ & Firmness $(\mathrm{N})$ & Fresh Mass $(\mathrm{g})$ \\
\hline Boqueirão* & $38.45 \mathrm{ab}^{* *}$ & $48.88 \mathrm{a}$ & $5.58 \mathrm{~b}$ & $47.64 \mathrm{a}$ \\
Solânea & $39.04 \mathrm{a}$ & $48.77 \mathrm{a}$ & $4.34 \mathrm{~b}$ & $46.05 \mathrm{a}$ \\
São Mamede & $35.80 \mathrm{~b}$ & $46.22 \mathrm{a}$ & $7.44 \mathrm{a}$ & $41.43 \mathrm{a}$ \\
\hline Mean (N) & 37.76 & 47.95 & 5.78 & 45.04 \\
C.V. (\%) & 15.84 & 12.66 & 51.51 & 33.23 \\
\hline
\end{tabular}

** Means followed by the same letter in the column do not differ by the Tukey test at $5 \%$ of probability. ${ }^{*} \mathrm{n}=40 ; \mathrm{N}=120$.

There was no difference among the three municipalities with regard to the diameter and fresh weight of the fruit. Size and fresh weight are determinants in the fresh fruit market and the processing industry, as it presents a higher yield of the fruit.
Fruits from São Mamede located in the Sertão region were firmer in relation to the other studied municipalities, and no evidence of mesocarp cracking was observed, which is a characteristic of xiquexique when the fruit reaches advanced maturity on the plant. This is important as the 
level of firmness is a postharvest quality attribute, especially regarding the handling and transportation of fruit and vegetables (PAREEK, 2016)

The physicochemical characteristics of xiquexique fruit differed among the municipalities for both the pulp and the peel. Fruit from Solânea showed a soluble solids (SS) content ranging from 3.12 to $5.12 \%$ in the peel (Table 2), which also presented the highest weight and length values. On the other hand, fruit from São Mamede had higher SS levels, and were lighter and smaller. High temperatures and low relative humidity, characteristic of semiarid climates, enhance plant transpiration and increase the loss rate of fruit weight (PAREEK, 2016). This may have resulted in smaller fruit sizes, and in turn a higher concentration of the cellular juice that consequently had increased SS content, justifying the higher SS values in the fruits from the São Mamede municipality. Herein, xiquexique fruit had an inferior SS content in the peel to those reported by Melo et al. (2017) in "mandacaru" (C. jamacaru) fruit (6.18\%).

The titratable acidity content in the xiquexique fruit differed in the peel of the evaluated municipalities, presenting Boqueirão with the highest and São Mamede with the lowest (Table 2). The fruit peel in the municipalities of Solânea and Boqueirão presented a lower SS/AT ratio, which relates to the lower SS levels found in this portion. The SS/AT ratio is indicative of fruit sweetness (PAREEK, 2016), so that fruits from these municipalities were less sweet.

Table 2. Content of soluble solids (SS), titratable acidity (TA), SS/TA ratio, $\mathrm{pH}$, ascorbic acid (AA) in the peel of ripe xiquexique (Pilosocereus gounellei (A. Weber ex K. Schum.)) fruits (purplish color), harvested from areas of occurrence of plant in three municipalities, state of Paraíba, Brazil.

\begin{tabular}{|c|c|c|c|c|c|}
\hline Municipality & SS (\%) & TA $\left(\mathrm{g}\right.$ citric acid $\left.100 \mathrm{~g}^{-1}\right)$ & $\mathrm{SS} / \mathrm{TA}$ & $\mathrm{pH}$ & $\mathrm{AA}\left(\mathrm{mg} 100 \mathrm{~g}^{-1}\right)$ \\
\hline Boqueirão & $3.67 b^{* *}$ & $0.22 \mathrm{a}$ & $16.79 \mathrm{~b}$ & $4.49 \mathrm{~b}$ & $7.45 \mathrm{~b}$ \\
\hline Solânea & $3.12 \mathrm{c}$ & $0.19 \mathrm{~b}$ & $16.07 \mathrm{~b}$ & $4.39 \mathrm{~b}$ & $8.97 \mathrm{a}$ \\
\hline São Mamede & $5.12 \mathrm{a}$ & $0.15 \mathrm{c}$ & $34.03 \mathrm{a}$ & $4.68 \mathrm{a}$ & $3.92 \mathrm{c}$ \\
\hline Mean $(\mathrm{N})$ & 3.97 & 0.18 & 22.30 & 4.52 & 6.78 \\
\hline C.V. $(\%)$ & 2.23 & 1.68 & 5.7 & 3.20 & 10.86 \\
\hline
\end{tabular}

** Mean followed by the same letter in the column do not differ by the Tukey test up to $5 \%$ of probability. ${ }^{*} \mathrm{n}=4 ; \mathrm{N}=120$.

The SS content in pulp varied from 7.14 to $12.45 \%$ (Table 3), being lower than those registered in the mandacaru fruit pulp, which was between 11.74 and $14.93 \%$ (MELO et al., 2017). In the peel, lower SS values in the fruit from Solânea and higher in the fruit from São Mamede were observed. For two species of pitaya (Hylocereus undatus and Selenicereus setaceus), Lima et al. (2014) reported that the larger the fruit size and weight, the lower the SS content in the pulp. This may be due to the tendency for smaller fruit to have higher concentrations of sugars and organic acids for the same species, whereas these contents are more dissolved in larger fruits (PAREEK, 2016), which may be related to the different climates and the way fruits of the same species respond to different conditions.

Aparicio-Fernández et al. (2017) reported SS in the pulp from $7.6 \%$ to $15.5 \%$ for different species of Opuntia spp. Thus, fruit from different cacti species present pulp with wide-ranging SS content, some of which are indicated for fresh consumption or for processing. 
Table 3. Content of soluble solids (SS), titratable acidity (TA), SS/TA ratio, $\mathrm{pH}$, ascorbic acid (AA) in the pulp (intense pink-purplish color) of ripe xiquexique (Pilosocereus gounellei (A. Weber ex K. Schum.)) fruits, harvested from areas of occurrence of plant in three municipalities, state of Paraíba, Brazil.

\begin{tabular}{cccccc}
\hline Municipality & SS (\%) & TA $\left(\mathrm{g}\right.$ citric acid $\left.100 \mathrm{~g}^{-1}\right)$ & $\mathrm{SS} / \mathrm{TA}$ & $\mathrm{pH}$ & $\mathrm{AA}\left(\mathrm{mg} 100 \mathrm{~g}^{-1}\right)$ \\
\hline Boqueirão* & $8.70 \mathrm{~b}^{* *}$ & $0.28 \mathrm{a}$ & $31.70 \mathrm{~b}$ & $4.37 \mathrm{ab}$ & $12.17 \mathrm{a}$ \\
Solânea & $7.14 \mathrm{c}$ & $0.23 \mathrm{~b}$ & $30.94 \mathrm{~b}$ & $4.31 \mathrm{~b}$ & $14.92 \mathrm{a}$ \\
São Mamede & $12.45 \mathrm{a}$ & $0.18 \mathrm{c}$ & $82.39 \mathrm{a}$ & $4.52 \mathrm{a}$ & $7.31 \mathrm{~b}$ \\
\hline Mean (N) & 3.97 & 0.18 & 22.30 & 4.52 & 6.78 \\
C.V. (\%) & 2.23 & 1.68 & 5.7 & 3.20 & 10.86 \\
\hline
\end{tabular}

**Means followed by the same letter in the column do not differ by the Tukey test up to $5 \%$ of probability. ${ }^{*} \mathrm{n}=4 ; \mathrm{N}=120$.

Titratable acidity (TA) in the pulp differed among regions. Fruit from São Mamede presented the lowest content $\left(0.18 \mathrm{~g}\right.$ citric acid $\left.100 \mathrm{~g}^{-1}\right)$, while the highest was obtained in fruit from Boqueirão

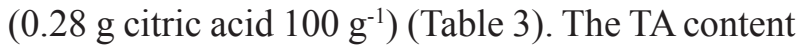
was close to those reported for fully red mandacaru fruit harvested from two bioclimates in the state of Paraíba (MELO et al., 2017).

Xiquexique fruit from São Mamede presented a higher SS/AT ratio (34.03) in the pulp, which is an important quality parameter as an indicator for fruit flavor evaluation because of the contribution of sweet and acidic components (PAREEK, 2016). Menezes et al. (2015) reported a SS/TA ratio of 39.14 for red pitaya at 41 days after anthesis when the fruit showed a red coloration, indicating full maturation. Dantas et al. (2015b) reported a SS/ TA ratio of 23 for Tacinga inamoena fruit. The authors described these fruits as sweet and suitable for fresh consumption. Therefore, the fruit pulp of the different municipalities studied herein showed a high SS/TA ratio with values of 31.70, 30.94 and 82.39 from Boqueirão, Solânea and São Mamede, respectively, which could be considered appropriate for fresh consumption.

Fruit from São Mamede showed higher $\mathrm{pH}$ values in both the pulp and peel, and may be considered lowly acidic because its values were higher than 4.5 (BADUI-DERGAL, 2012). The fruit from other municipalities were slightly acidic. Aparicio-Fernández et al. (2017) reported that the fruit of different Opuntia spp. varieties has $\mathrm{pH}$ ranging from 4.8 to 7.2 in the pulp.

The ascorbic acid content in the xiquexique fruit peels ranged from 3.92 to $8.97 \mathrm{mg} 100 \mathrm{~g}^{-1}$, being higher in fruit from Solânea. In turn, the lowest values were those in fruit from São Mamede in both the peels and pulp. Beltrán-Orozco et al. (2009) reported similar values in the fruit pulp of four pitaya varieties, with ascorbic acid content ranging from 8.0 to $14.0 \mathrm{mg} 100 \mathrm{~g}^{-1}$.

The total extractable polyphenols (TEP) content in fruit from Solânea was the highest in both the peel (Figure 2A) and pulp (Figure 2B). Albano et al. (2015) reported a value of $89.2 \mathrm{mg}$ GAE $100 \mathrm{~g}^{-1}$ in the pulp of a purple Opuntia ficus-indica variety, being superior to those found in this research for xiquexique fruit from different municipalities. In Tacinga inamoena fruit, Dantas et al. (2015c) reported lower levels than those reported herein (29.84 mg GAE $\left.100 \mathrm{~g}^{-1}\right)$.

The amount of TEP can vary among the portions of the same fruit within the family, depending on the species. Fruit from São Mamede showed the lowest TEP content in the peel, but the values were close to those from Boqueirão for the pulp. It is worth mentioning that the xiquexique fruit pulp presented higher TEP content than the peel, regardless of the municipality. This fact is associated with the high betalain content present in the pulp, since the methanol used in the polyphenol extracting solution also has the ability to extract betalains. 
This may have resulted in greater quantification of the phenolic compounds in the pulp, since these pigments especially occur in the stronger staining portions between red and purple (YAHIA; MONDRAGON-JACOBO, 2011).

Figure 2. Total Extractable Polyphenols (TEP) in the peel (A) and pulp (B) of ripe xiquexique (Pilosocereus gounellei (A. Weber ex K. Schum.)) fruits, harvested from areas of occurrence of plant of three municipalities of the state of Paraíba, Brazil.
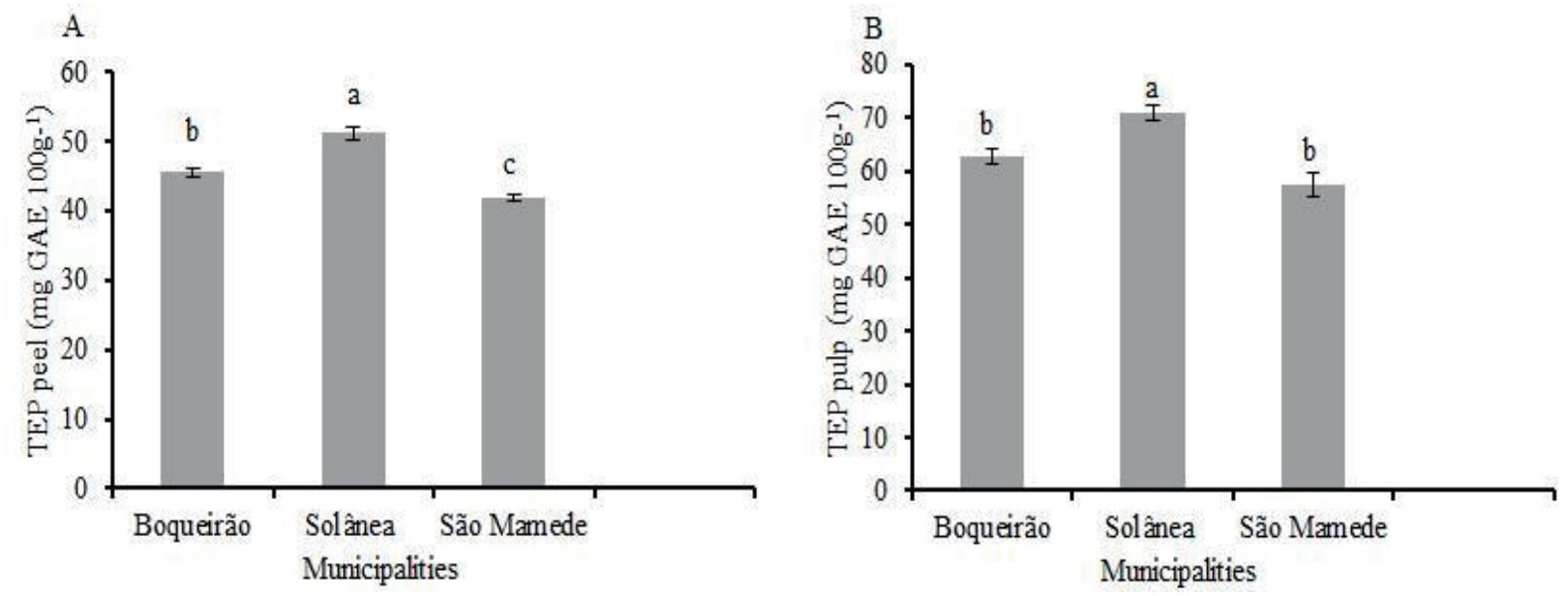

Bars followed by the same letter do no differ by the Tukey test at $5 \%$ of probability. $n=4$.

Fruit pulp presents the highest content of betalains, betacyanins and betaxanthins (Figure 3B). Fruit grown in Solânea had higher total betalain content when compared to the other municipalities, both in the peel and in the pulp. Considering the peel portion, fruit from Solânea was $13.2 \%$ higher than the fruit from Boqueirão, and 17.4\% higher in relation to those from São Mamede. Fruit from Solânea presented $9.6 \%$ higher total betalain content than fruit from Boqueirão, and 12.2\% higher than fruit from São Mamede considering the pulp portion. However, fruit grown in Boqueirão and São Mamede did not differ between them. These results may be related to the more intense purple red coloration that the fruit pulp from Solânea presented.

The betacyanin content differed among the fruit peels grown in the three municipalities. In Solânea, the fruit presented $11.41 \%$ higher levels than those from Boqueirão, and 20.5\% higher than those from São Mamede. For betaxanthins, fruit grown in Solânea had $15.6 \%$ higher content than those from Boqueirão, and 13.4\% higher than those from São Mamede (Figure 3A). The fruit content of these last two municipalities did not differ. The betacyanin contents in the pulp only differed in fruit from Solânea, being 9.7\% higher in Boqueirão and 13.5\% higher in São Mamede. Betacyanins are associated with a red-violet color, justifying the higher content of this pigment in the xiquexique pulp compared to betaxanthins, since the pulp of this fruit shows pinkpurplish coloration. Sumaya-Martínez et al. (2011) also reported high betacyanin levels to the same order of those obtained in this work in the fruit from 18 varieties of Opuntia spp. with a purple coloration produced in Mexico. The betaxanthin content did not differ among the fruit pulp from the different municipalities studied (Figure 3B). 
Figure 3. Total betalains, betacyanins and betaxanthins content in the peel (A) and pulp (B) of ripe xiquexique (Pilosocereus gounellei (A. Weber ex K. Schum.)) fruits, harvested from areas of occurrence of plant in three municipalities of the state of Paraíba, Brazil.
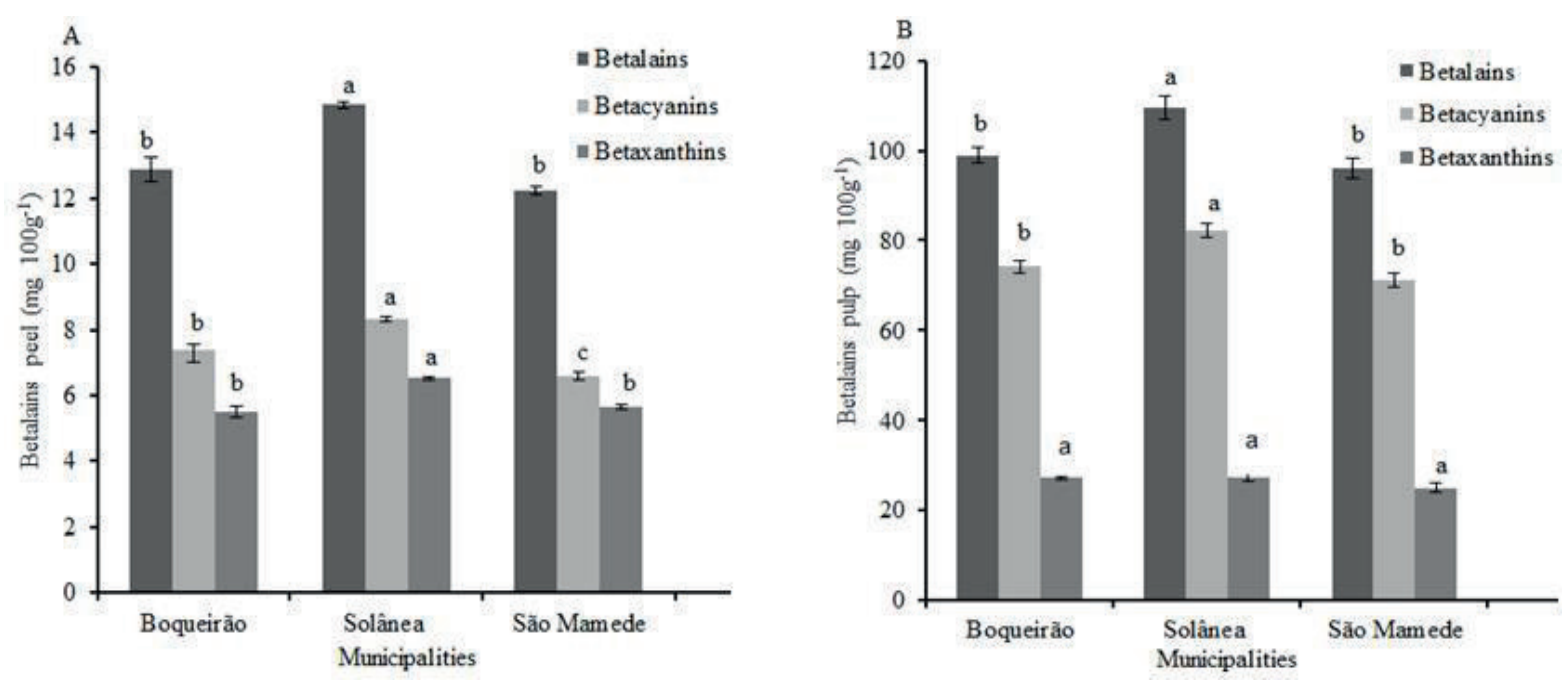

Bars followed by the same letter do no differ by the Tukey test at $5 \%$ of probability. $n=4$.

Based on the presented results, it is noticeable that xiquexique fruit pulp can be an important source of betalains, compounds of functional and nutritional interest. According to Castellar et al. (2003), natural red pigments from plants are of growing interest as substitutes for synthetic red dyes in the food industry. The betacyanin values found in the xiquexique fruit in this study were higher than those reported by Albano et al. (2015) in the pulp of a purple variety of Opuntia ficus-indica fruit, with $39.3 \mathrm{mg} 100 \mathrm{~g}^{-1}$. Dantas et al. (2015c) also

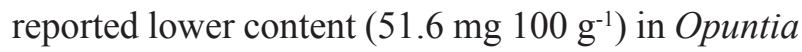
stricta fruit. However, Garcia et al. (2012) reported higher levels of total betalain (347.3 mg $100 \mathrm{~g} \mathrm{~g}^{-1}$ ), betacyanins (199.6 mg $100 \mathrm{~g}^{-1}$ ) and betaxanthins (147.61 mg $100 \mathrm{~g}^{-1}$ ) for purple pitaya. Therefore, a variation in the content of these pigments is observed within the Cactaceae family, according to the portion and the species studied.

The DPPH ${ }^{*-1}$ radical method means that the lower the value of $\mathrm{EC}_{50}$, the higher the antioxidant activity of the sample. Therefore, it was observed that the xiquexique fruit pulp presents higher antioxidant activity when compared to the peel in the fruit from all 3 municipalities. Abreu et al. (2012) also identified greater antioxidant activity in red pitaya pulp compared to the peel. Dantas et al. (2015a) reported values of $2.153 \mathrm{~g} \mathrm{FW} \mathrm{g} \mathrm{DPPH}^{* 1}$ in Tacinga inamoena fruit pulp, and $1.730 \mathrm{~g} \mathrm{FW} \mathrm{g} \mathrm{DPPH}^{\cdot-1}$ in Opuntia stricta, indicating that the latter had higher antioxidant activity. This value is close to those found in the xiquexique fruit pulp of this study.

A higher antioxidant activity was observed in the fruit peels from São Mamede and Boqueirão, and fruit grown in Solânea had lower antioxidant activity (Figure 4A). However, fruit from São Mamede presented higher antioxidant activity when the pulp is considered (Figure 4B).

The highest antioxidant activity attributed to the xiquexique fruit pulp may be associated with the higher phenolic compound content. Pearson's correlation (Table 4) among the phenolic compounds and its antioxidant activity by the $\mathrm{DPPH}^{-1}$ method was much higher in the peel $\left(\mathrm{r}=0.84^{* *}\right)$ than in the pulp $\left(\mathrm{r}=0.68^{*}\right)$, and a high correlation was also observed for betaxanthin content $\left(\mathrm{r}=0.87^{* *}\right)$ in the pulp. Vaillant et al. (2005) attributed the high 
antioxidant activity of red pitaya pulp to the high the antioxidant activity of plants is correlated to the phenolic compound and betacyanin contents. Yahia phenolic compound and betalain contents. and Mondragon-Jacobo (2011) also highlighted that

Figure 4. Antioxidant Activity $\left(\mathrm{EC}_{50}\right)$ in the skin $(\mathrm{A})$ and pulp (B) of ripe xiquexique (Pilosocereus gounellei) fruits, harvested from areas of occurrence of plant in three municipalities of the Paraíba state, Brazil.
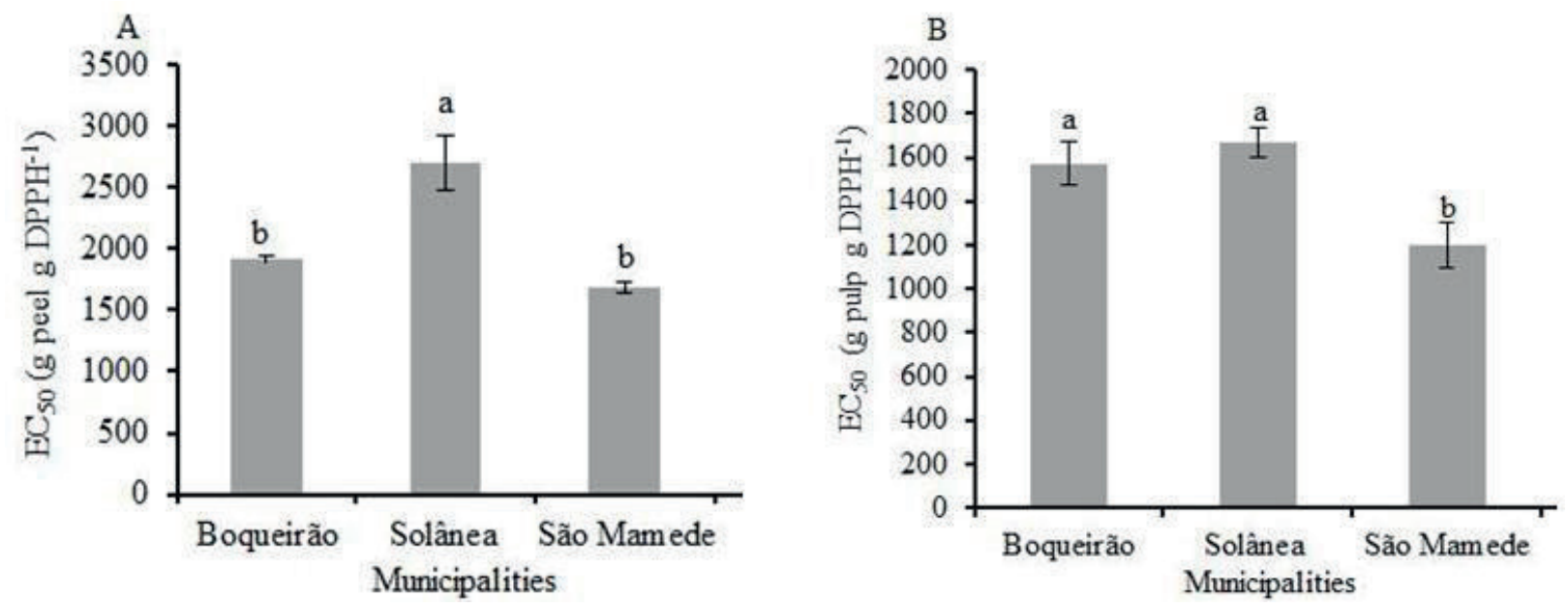

Bars followed by the same letter do no differ by the Tukey test at $5 \%$ of error probability. $n=4$.

Table 4. Pearson's correlation of the bioactive compounds and antioxidant activity of ripe xiquexique (Pilosocereus gounellei (A. Weber ex K. Schum.)) fruits, harvested from areas of occurrence of plant in three municipalities, state of Paraíba, Brazil.

\begin{tabular}{cccccccccc}
\hline & DPPH-Pe & DPPH-Pu & TEP-Pe & TEP-Pu & BTC-Pe & BTX-Pe & TBL-Pe & BTC-Pu & BTX-Pu \\
\hline DPPH-Pu & $0.64^{*}$ & & & & & & & & \\
TEP-Pe & $0.64^{*}$ & $0.84^{* *}$ & & & & & & & \\
TEP-Pu & $0.68^{*}$ & $0.80^{* *}$ & $0.90^{* *}$ & & & & & & \\
BTC-Pe & $0.68^{*}$ & $0.85^{* *}$ & $0.94^{* *}$ & $0.96^{* *}$ & & & & & \\
BTX-Pe & $0.32^{\text {ns }}$ & $0.81^{* *}$ & $0.83^{* *}$ & $0.82^{* *}$ & $0.82^{* *}$ & & & & \\
TBL-Pe & $0.56^{\text {ns }}$ & $0.87^{* *}$ & $0.94^{* *}$ & $0.95^{* *}$ & $0.97^{* *}$ & $0.93^{* *}$ & & & \\
BTC-Pu & $0.64^{*}$ & $0.88^{* *}$ & $0.90^{* *}$ & $0.86^{* *}$ & $0.90^{* *}$ & $0.84^{* *}$ & $0.92^{* *}$ & & \\
BTX-Pu & $0.48^{\text {ns }}$ & $0.74^{* *}$ & $0.58^{*}$ & $0.57^{\text {ns }}$ & $0.64^{*}$ & $0.72^{* *}$ & $0.70^{* *}$ & $0.83^{* *}$ & \\
TBL-Pu & $0.62^{*}$ & $0.87^{* *}$ & $0.85^{* *}$ & $0.82^{* *}$ & $0.87^{* *}$ & $0.84^{* *}$ & $0.90^{* *}$ & $0.99^{* *}$ & $0.90^{* *}$ \\
\hline
\end{tabular}

DPPH-Pu:DPPH Pulp; DPPH-Pe:DPPH Skin; TEP-Pe: TEP Peel; TEP-Pu: TEP Pulp; BTC-Pe: Betacyanins Peel, BTX-Pe: Betaxanthins Peel, TBL-Pe: Total Betalains Peel, BTC-Pu: Betacyanins Pulp, BTX-Pu: Betaxanthins Pulp, TBL-Pu, Total Betalains Pulp.

\section{Conclusions}

In conclusion, xiquexique fruit presents intense pink-purplish pulp, an oblong shape (diameter greater than length), and a high SS/AT ratio, although showing a low soluble solids content for both the peel and the pulp. Fruit grown in Solânea presented greater ascorbic acid content.

Xiquexique (P. gounellei (A. Weber ex K. Schum.)) can be considered as an excellent source of phenolic compounds and betalains, mainly in 
its fruit pulp, and independent of the region where they occur. It also presents high antioxidant activity by the $\mathrm{DPPH}^{\cdot-1}$ radical method. According to these results, xiquexique fruit pulp has the potential to compose functional foods, as well as for extracting high value-added compounds, which can promote agricultural development in the Semiarid region.

\section{References}

ABREU, W. C.; LOPES, C. O.; PINTO, K. M.; OLIVEIRA, L. A.; CARVALHO, G. B. M.; BARCELO, M. F. P. Características físico-químicas e atividade antioxidante total de pitaias vermelha e branca. Revista Instituto Adolfo Lutz, São Paulo, v. 71, n. 4, p. 656-61, 2012.

ALBANO, C.; NEGRO, C.; TOMMASI, N.; GERARDI, C.; MITA, G.; MICELI, A.; DE BELLIS, L.; BLANDO, F. Betalains, phenols and antioxidant capacity in cactus pear [Opuntia ficus-indica (L.) Mill.] Fruits from Apulia (South Italy) genotypes. Antioxidantes, Basel, v. 4, n. 2, p. 269-280, 2015.

APARICIO-FERNÁNDEZ, S.; LOZA-CORNEJO, M. G.; TORRES-BERNAL, N. J.; VELÁZQUEZPLACENCIA, Y. H. J.; ARREOLA-NAVA. Características fisicoquímicas de frutos de variedades silvestres de Opuntia de dos regiones semiáridas de Jalisco. Polibotanica, Cidade do México, v. 10, n. 43, p. 219-244, 2017.

ARAUJO, K. D.; DANTAS, R. T.; ANDRADE, A. P.; PARENTE, H. N.; ÉDER-SILVA, E. Uso de espécies da Caatinga na alimentação de rebanhos no município de são João do Cariri - PB. Revista RA'E GA, Curitiba, n. 20, p. 157-171, 2010.

BADUI-DERGAL, S. Clases de alimentos. En: LÓPEZ BALLESTEROS, G. Y.; GUTIÉRREZ HERNÁNDEZ, B. (Ed.). La Ciencia de los alimentos en la práctica. PEARSON, México, 2012. p. 171-178.

BELTRÁN-OROZCO, M. C.; OLIVA-COBA, T. G.; GALLARDO-VELÁZQUEZ, T.; OSORIO-REVILLA, G. Ascorbic acid, phenolic content, and antioxidant capacity of red, cherry, yellow and white types of pitaya cactus fruit (Stenocereus stellatus Riccobono). Agrociencia, Texcoco, v. 43, n. 2, p. 1405-3195, 2009.

CASTEllaR, M. R.; SOLANO, F.; OBÓN, J. M. Betacyanin and other antioxidants production during growth of Opuntia stricta (Haw.) fruits. Plant Foods for Human Nutrition, Dordrecht, v. 67, n. 4, p. 337-343, 2012.
CASTELLAR, R.; OBÓN, J. M.; ALACID, M.; FERNÁNDEZ-LÓPEZ, J. A. Color properties and stability of betacyanins from Opuntia fruits. Journal Agricultural Food Chemistry, Washington, v. 51, n. 9, p. 2772-2776, 2003.

DANTAS, R. L.; SILVA, S. M.; BRITO PRIMO, D. M.; SOUSA, A. S. B.; BRITO, E. S.; MACEDO, E. M. S. Changes during maturation in the bioactive compounds and antioxidant activity of Opuntia stricta (Haw.) fruits. Acta Horticulturae, Leuven, v. 1067, n. 21, p. 159-165, 2015a.

DANTAS, R. L.; SCHÜNEMANN, A. P. P.; SILVA, S. M.; SILVA, R. S.; MELO, R. S.; SOUSA, F. A. R. M. Quality and descriptive terminology of Tacinga inamoena (K. Schum.) fruits. Acta Horticulturae, Leuven, v. 1067, n. 19, p. 143-149, 2015 b.

DANTAS, R. L.; SILVA, S. M.; SANTOS, L. F.; DANTAS, A. L.; LIMA, R. P.; SOARES, L. G. Betalains and antioxidant activity in fruits of Cactaceae from Brazilian Semiarid. Acta Horticulturae, Leuven, v. 1067, n. 20 , p. $151-157,2015 \mathrm{c}$.

GARCÍA-CRUZ, L.; SALINAS-MORENO, Y.; VALLEGUADARRAMA, S. Betalaínas, Compuestos Fenólicos y Actividad antioxidante en Pitaya de mayo (Stenocereus griseus H.). Revista Fitotecnia, Texcoco, v. 35, n. 5, p. $1-5,2012$.

LI-CHAN, E. V. Y. Bioactive Peptides and protein hydrolysates: research trends and challenges for application as nutraceuticals and functional food ingredients. Current Opinion in Food Science, Amesterdan, v. 1, n. 5, p. 28-37, 2015.

LIMA, C. A.; FALEIRO, F. G.; JUNQUEIRA, N. T. V.; BELLON, G. Avaliação de características físicoquímicas de frutos de duas espécies de pitaya. Revista Ceres, Viçosa, v. 61, n. 3, p. 377-383, 2014.

LUCENA, C. M.; LUCENA, R. F. P.; COSTA, G. M.; CARVAlHO, T. K. N.; COSTA, G. G. S.; ALVES, R. R. N.; PEREIRA, D. D.; RIBEIRO, J. E. S.; ALVES, C. A. B.; QUIRINO, Z. G. M.; NUNES, E. N. Use and knowledge of Cactaceae in Northeastern Brazil. Journal of Ethnobiology and Ethnomedicine, London, v. 9, n. 62, p. 1-11, 2013.

MELO, R. S.; SILVA, S. M.; SOUSA, A. S. B.; LIMA, R. P.; DANTAS, A. L.; DANTAS, R. L.; FIGUEIREDO, V. M. A. Maturação e qualidade de frutos de mandacaru (Cereus jamaracu P.DC.) de diferentes bioclimas do estado da Paraíba. Revista Agropecuária Técnica, Areia, v. 38, n. 3, p. 160-168, 2017.

MENEZES, T. P.; RAMOS, J. D.; LIMA, L. C. O.; COSTA, A. C.; NASSUR, R. C. M. R.; RUFINI, J. C. 
M. Características físicas e físico-químicas de pitaia vermelha durante a maturação. Semina: Ciências Agrárias, Londrina, v. 36, n. 2, p. 631-644, 2015.

MOUSSA-AYOUB, T. E.; EL-SAMAHY, S. K.; KROH, L. W.; ROHN, S. Identification and quantification of flavonol aglycons in cactus pear (Opuntia ficus indica) fruit using a commercial pectinase and cellulase preparation. Food Chemistry, Amesterdan, v. 124, n.32, p. 1177-1184, 2011.

PAREEK, S. Postharvest ripening physiology of fruits. Innovations in postharvest technology series. Boca Raton: CRC Press -Taylor and Francis Group, 2016. 664 p.

SBRISSA, F. C.; MELO, A. G. C. Conservação morfológica e conservação de Anthocereus odorus F. Ritter. Revista Eletrônica de Engenharia Florestal, v. 20, n. 1, 2012 .

SILVA, S. M.; BRITO PRIMO, D. M.; TORRES, L. B. V.; MARTINS, L. P.; LIMA, A. B.; SILVA, F. V. G. Features of postharvest physiology and quality of cacataceae fruits from Brazilian Northeast. Acta Horticulturae, Louven, v. 811, n. 11, p. 113-122, 2009.
SPENCER, J. P.; ABD, E. L.; MOHSEN, M. M.; MINIHANE, A. M.; MATHERS, J. C. Biomarkers of the intake of dietary polyphenols: strengths, limitations and application in nutrition research. Br. Journal of Nutrition, Epub, v. 99, n. 12, p. 12-22, 2008.

SUMAYA-MARTÍNEZ， M. T.; JAIME， S. C.; SANTILLÁN, E. M.; PAREDES, J. D. G.; CORTÉS, R. C.; CANSINO, N. C.; VEGA, C. V.; CARDENAS, L. M.; GARCÍA, E. A. Betalain, Acid ascorbic, phenolic contents and antioxidant properties of purple, red, yellow and white cactus pears. International Journal of Molecular Sciences, Basel, v. 12, n. 10, p. 6452-6468, 2011.

VAILLANT, F.; ANA, P.; INDIANA, D.; MANUEL, D.; MAX, R. Colorant and antioxidant properties of redpurple pitahaya (Hylocereus sp.). Fruits, Cambridge, v. 60 , n. 1, p. 3-12, 2005.

YAHIA, E. M.; MONDRAGON-JACOBO, C. Nutritional components and anti-oxidant capacity of ten cultivars and lines of cactus pear fruit (Opuntia spp.). Food Research International, London, v. 44, n. 7, p. 2311-2318, 2011. 